\title{
Entre a Literatura e o Jornalismo: Itinerários do Escritor Baiano Anísio Melhor (1885-1955)
}

\section{Resumo:}

Anísio Melhor nasceu na cidade de Nazaré, situada no Recôncavo da Bahia, no dia 07 de maio de 1885. Da leitura de sua obra, mais importante fonte de informações encontradas sobre o escritor, percebe-se que o jornalismo e a sua vida mesclam-se. Autodidata, foi nos jornais que dirigiu e colaborou que se revelou poeta, romancista, contista, crítico literário, folclorista e cronista. Dentre os gêneros literários que publicou em periódicos, as crônicas são os textos que mais evidenciam o seu modus scribendi, bem como apontam pistas de seu percurso intelectual e de sua evolução como escritor. Em alguns de seus textos, discorre sobre o trabalho solitário do jornalista, aliando aos seus escritos as suas vivências enquanto leitor de jornais dos mais variados e, especialmente, enquanto jornalista da sua pequena cidade. Segundo o escritor, o jornal de interior valoriza cada leitor de sua cidadezinha, conhece seu público muito de perto, anota dia a dia os acontecimentos: ora é a crônica de cunho social, ora é o comentário sobre os falecimentos, ora é a poesia telúrica, ora é o nascimento de mais uma criança, ora é o capítulo de mais uma novela ou romance. Assim, no jornal que fundou e dirigiu por algumas décadas, O Conservador (1912-1945), (re)construía, a cada dia, a história da sua gente, registrava as suas tradições, histórias e memórias. As pesquisas realizadas em acervos literários para a composição deste artigo contribuíram para reavivar a memória deste escritor e divulgar a sua produção literária e seu trabalho como jornalista.

Palavras-chave:

Anísio Melhor, literatura, jornalismo

Abstract:

Anísio Melhor was born in the city of Nazaré, located in the Recôncavo da Bahia, on May 7, 1885. From reading his work, the most important source of information found about the writer, it is clear that journalism is one with his life. Self-taught, it was in the newspapers that he directed and collaborated that he became a poet, novelist, short-story writer, literary critic, folklorist and chronicler. Among the literary genres he published in periodicals, chronicles are the texts that most show his modus scribendi, as well as pointing out clues to his intellectual path and his evolution as a writer. In some of his texts, he discusses 
the journalist's solitary work, combining his experiences as a reader of the most varied newspapers and, especially, as a journalist in his small town. According to the writer, the provincial newspaper values every reader in its small town, knows its audience very closely, writes down the events day by day: now it is the chronicle of social nature, now it is the commentary on the deaths, now it is telluric poetry, now it is the birth of another child, now it is the chapter of another novel or novella. Thus, in the newspaper he founded and directed for a few decades, O Conservador (1912-1945), Melhor every day (re)constructed the history of his people, recording their traditions, stories and memories. The researches carried out in literary archives for the composition of this article contributed to revive the memory of this writer and to divulge his literary production and his work as a journalist.

Keywords:

Anísio Melhor, literature, Journalism

\section{Introdução}

A atividade de pesquisa em acervos de escritores, apoiada na ciência da Filologia, ao lidar com fontes primárias tendo em vista a organização, a catalogação de seus escritos, de suas publicações, traz à tona o escritor e a sua obra. As fontes primárias, como afirmam Regina Zilberman, Maria Eunice Moreira, Maria da Glória Bordini e Maria Luiza Ritzel Remédios (2004), podem compreender todo material utilizado pelo artista, seja na fase de gestação, seja de produção de sua obra: as suas recordações de infância, seus sonhos, histórias particulares ou coletivas, a tradição local ou nacional, seus escritos, suas leituras.

Esta pesquisa, em acervos literários, apresenta um pouco sobre a vida e a produção literária de Anísio Melhor (1885-1955), escritor baiano, da cidade de Nazaré, que compôs uma obra que se impõe pela diversidade de gêneros literários: novelas, poemas, artigos sobre o folclore regional, trovas, peças teatrais, crônicas, contos. Tornar transparente essa produção, desvelar as incursões literárias do escritor e o seu papel como jornalista, e destacar a importância documental do conjunto de sua obra, constituem alguns dos objetivos deste artigo. Deve-se acrescentar também a estes objetivos assinalados a necessidade de apresentar ao leitor comum e aos estudiosos da literatura um escritor pouco lido na atualidade, apesar da sua intensa produção literária na primeira metade do século XX.

Apresenta-se um pouco sobre a história de vida do autor a fim de caracterizar o contexto histórico-social em que ele viveu. Registra-se sua atuação como jornalista, fundando jornais noticiosos, literários e políticos em sua cidade natal. Registra-se a sua originalidade na construção de suas narrativas, que reside na sua busca por um efeito poético/metafórico entremeado de folclore e memória, visto que as tradições orais do Recôncavo Baiano - lundus, cantigas, trovas, lendas - são acopladas à sua novelística e contribuem para dar forma à cidade natal do autor e a outras localidades do Recôncavo Baiano (as praias, por exemplo) e revelam o olhar de um jornalista-literato-folclorista enamorado de sua terra e de sua gente. 
Para empreender este estudo, foram realizadas pesquisas em arquivos baianos, públicos e particulares, com o objetivo de encontrar seus textos dispersos em periódicos e a sua fortuna crítica, bem como para obtenção de informações sobre a literatura baiana no século XX. O presente estudo foi dividido em três partes, a saber: a primeira, intitulada Anísio Melhor: um homem multifacetado, apresenta suscintamente aspectos biográficos do escritor, colhidos nos acervos particulares e públicos visitados; na segunda parte, intitulada Entre o jornalismo e a literatura, discorre-se sobre as incursões literárias do escritor, bem como a sua dedicação ao jornalismo, baseando-se no seu livro Idéias e emoções - Folhetins d'O Conservador; a terceira parte do estudo, intitulada Novelas de folhetins: retratos do Recôncavo Baiano na novelística de Anísio Melhor, apresenta algumas características de suas novelas, que foram publicadas capítulo a capítulo no jornal, antes de serem publicadas em livro.

\section{Anísio Melhor: um homem multifacetado}

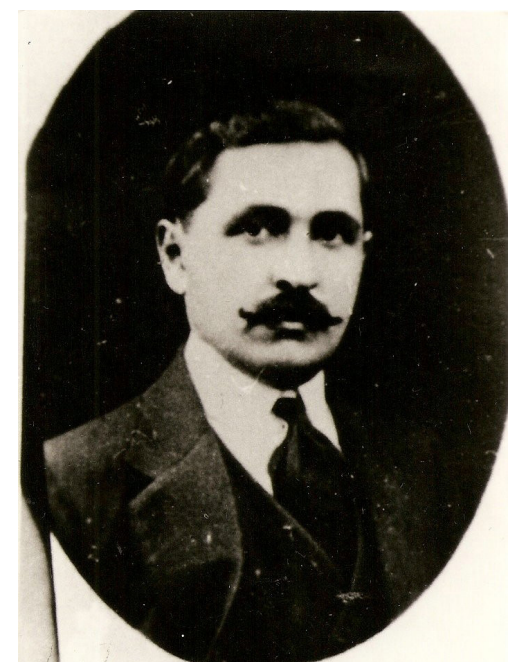

Figura 1 - Fotografia do escritor Anísio Melhor.

Fonte: O Conservador, 1920. Acervo da Biblioteca Pública do Estado da Bahia.

Buscou-se, especialmente, na produção literária do escritor Anísio Melhor, informações que permitiram resgatar o homem, o cronista, o educador, o poeta, o romancista, o crítico literário, o pesquisador do folclore do Recôncavo Baiano. A obra anisiana encontra-se dispersa em arquivos na capital baiana e na cidade natal do escritor, Nazaré. Anísio Melhor nasceu na cidade de Nazaré situada no Recôncavo Baiano, no dia 07 de maio de 1885. Viveu toda sua infância e adolescência numa modesta casa localizada à rua do Batatan, atual rua Deputado Manoel Lopes Bittencourt, na antepenúltima casa do final da rua, número 145, conforme documento datilografado, localizado no acervo da Fundação Lamartine Augusto (em Nazaré). Era filho do comerciante Manoel Gonçalves Melhor e Sofia Amélia de Jesus Santos. O seu pai, o Sr. Manoel, 
era dono da maior padaria e mercearia do bairro do Batatan, em Nazaré. Anísio Melhor era o filho mais velho de Dona Sofia e do Sr. Manoel, teve apenas um irmão, que se chamava Antonio dos Santos Melhor, que foi prefeito da cidade por dois mandatos. Seus avós paternos eram José Gonçalves Melhor e Dona Maria Augusta Gonçalves Melhor e os avós maternos o Sr. José Leandro dos Santos e Dona Joanna de Jesus Santos.

Conforme leitura de depoimentos de amigos e admiradores, Anísio Melhor foi um homem de coração bondoso, de conversa agradável, de voz doce. Era de feições bonitas e mantinha um bigode de seda, à Castro Alves - como se pode notar na fotografia apresentada na abertura desta seção. Do ponto de vista filosófico e religioso, o poeta era católico e foi membro da Loja Maçônica Fraternidade Nazarena, e também pertenceu à Fraternidade Esotérica da Comunhão do Pensamento, cuja sede está localizada em São Paulo. Homem puro, humano e abnegado, sentimental, de ar solitário e discreto, não era afeito aos tumultos da multidão, mas possuía um vasto círculo de amigos muito fiéis.

Em Nazaré, fez apenas o curso elementar, ou de primeiro grau. Todo conhecimento adquirido a partir daí é resultado de sua dedicação pessoal aos estudos, o que fez dele um autodidata. Conforme os relatos do amigo, admirador e colecionador de suas obras, Oswaldo Crusoé:

Quem o visse folheando gramáticas de várias línguas, jamais acreditaria que aquele simples empregado da "Padaria Batatan" do Sr. Melhor, situada à Rua do Batatan, hoje Rua Deputado João Bittencourt, lia obras de Dante, Musset, Cervantes e até Goethe na língua original, legando também às letras de sua terra natal, páginas encantadoras de poesia regionalista, nos livros que escreveu. (Crusoé 1978: f. 2)

Homem muito respeitado e admirado por todos, Anísio Melhor participou efetivamente da vida cultural da sua cidade natal. Seu autodidatismo foi exaltado por escritores e jornalistas. Dentre os jornais de sua época, pode-se citar O Paládio da cidade de Santo Antônio de Jesus, fundado em 15 de novembro de 1901, que apresenta a notícia intitulada "Os que se distinguem pelo próprio esforço". Nela o autor, o diretor e proprietário do jornal, Antônio Mendes Araújo, expressa sua admiração à inteligência de Anísio Melhor:

São raros, na Bahia, os homens de saber, gerados em atmosfera sem dilatações e amplitudes. Raros e admiráveis.

Dessa estirpe, temos perto de nós um exemplo, um diamante de primeira água, de raro brilho: Anísio Melhor. (Araújo 1945: 1)

As suas memórias da infância, dos tempos da mercearia do seu pai, são evocadas em seus textos. O seu soneto "O fechar-se o comércio às 8 horas" é um exemplo disso. Trata-se de um poema com doses de humor, em homenagem às leis trabalhistas. Nele o poeta apresenta suas lembranças de quando começou a trabalhar, ainda menino, como caixeiro, no já referido estabelecimento de seu pai: 
Que felizardo agora é o caixeiro!

Pudera, às oito horas dando o fora!

Tomar seu banho pelo corpo inteiro,

$\mathrm{E}$ ir à rua onde a menina mora!

Oh! meu tempo em que fui, sem ter dinheiro,

Vendedor de aguardente a toda hora!

De calcinhas de brim, soço e sombreiro

Desses de dois mil réis à venda agora!

A lei foi uma lei muito bem justa,

Balcão! Eu cá sei bem quanto isso custa!

Caixeiros vos vingastes em segredo!

Coitado é do patrão que vive aflito,

Que em casa é recebido sempre a grito,

E se vê obrigado a ir mais cedo!

(Melhor apud Matta 1990: 191-192)

Também apresenta, em seus poemas, os seus sonhos e devaneios, suas tristezas e alegrias, sua solidão. O poeta refugia-se nos próprios versos, como a usá-los para exteriorizar e compreender sua realidade interior. Há momentos em que a dor motiva-o a criar. $O$ desânimo, a desesperança, o desalento, o desgosto são cantados em "Simples", poema que abre o seu primeiro livro, intitulado Meus Versos, publicado em 1911:

Quero da tarde sob a tutela

Deixar a vida, bem ao sol-posto;

Já que não tive nenhuma estrella

Na noite amarga do meu desgosto.

Cantem cantigas e bem magoadas

Todos os tristes, todos por mim.

- Nossa Senhora das Sete-Espadas

Minhas tristezas são bem assim.

Bem quero a morte, que a mim a morte

Não é tristeza, tão bem o sei!

Tristezas tive sempre por sorte

Do meu destino foi dura lei.

(Melhor 1911: 1) 
Além deste livro de poemas, muitos sonetos e trovas foram publicados diariamente nas páginas de $O$ Conservador e ainda não houve quem os reunisse em um estudo. Em suas crônicas, o autor revela imagens de sua infância, como em "Amigos Mortos - das memórias de minhas memórias" (idem: 2), em que relata seu convívio, quando criança, com um grupo de ex-escravos que residia no bairro em que nasceu; eram cerca de cinquenta pessoas advindas de várias regiões da África. Conforme o autor, em sua crônica, viviam todos de pequenas roças, mercados de frutas e quitutes de origem africana, os quais comercializavam na feira de Nazaré. No mesmo texto, afirma que seu pai "tornara-se uma sombra amiga para aquela gente, fiscalizando as suas compras de terras e de mocambos, garantindo-lhes na polícia as suas danças e rituais e até casando-os na Igreja do bairro" (ibidem).

O poeta, ainda menino, atendia esses homens e mulheres no balcão da mercearia, falando a língua deles, que, impulsionado pela curiosidade, aprendeu a falar. E ouvia-lhes suas histórias, suas crenças, seus sonhos, suas dores. Dessa sua curiosidade pela cultura africana, dessa sua proximidade com eles, ouvindo-os e aprendendo com esses seus amigos, Anísio Melhor volta o seu olhar para os elementos culturais que colaboraram na composição das tradições orais de sua região.

Na luta contra o apagamento dessas tradições, o escritor apega-se ao telúrico (ou seja, aos elementos da sua terra) e às suas memórias para compor poemas e narrativas. A este respeito o estudioso David Lowenthal (1998, p. 83) defende que relembrar o passado é crucial para que o sentido de identidade seja compreendido, a continuidade de uma comunidade depende inteiramente da memória, daí a importância em recordar experiências vividas no passado, porque elas ligam as pessoas aos seus selves anteriores, por mais diferentes que tenham se tornado. Assim, são das "memórias de suas memórias" que Anísio Melhor (re)escreve sua história e a história de sua terra, um processo de intersecção entre suas experiências vividas, a memória coletiva e a experiência de criar através da linguagem verbal.

A imprensa representou um importante veículo para a divulgação de suas produções literárias. Foi colaborador atuante de vários jornais nazarenos, como, por exemplo, o Conservador, fundado por ele em companhia dos conterrâneos Edgard Matta e Militão Santos em 05 de maio de 1912, semanário que se fez importante veículo de informação no Recôncavo Baiano, até o ano de 1942; foi redator de 0 Regenerador, periódico que circulou entre 1801 e 1929; e do jornal político A Semana; além disso, fundou a revista literária A Cigarra em 1914, que circulou por onze meses, e o semanário O Olho da Rua em 1923; muitas de suas criações apareceram nesses espaços e proporcionaram-lhe um número razoável de leitores.

A maioria dos jornais dos quais participou, bem como os livros que publicou, eram impressos na tipografia criada por ele, a Tipografia do Asilo de Meninos. Este asilo funcionava nas dependências do Colégio Manoel Clemente Caldas, uma instituição particular, da qual era o proprietário, diretor e professor de várias disciplinas. A instituição desenvolvia um trabalho filantrópico acolhendo meninos, sem lar, sem família. Na instituição, essas crianças moravam, estudavam gratuitamente e aprendiam uma profissão (alfaiataria, tipografia, datilografia, entre outras). 
Tornou-se membro correspondente da Academia de Letras da Bahia em 1932, publicou muitos textos na Revista da referida Academia e foi Patrono da cadeira de número cinco da Academia de Letras de Ilhéus.

Anísio Melhor viveu em sua terra natal até o ano de 1948, quando, por motivos financeiros, viu-se obrigado a deixar a Direção do Ginásio Clemente Caldas. O poeta deixa sua terra natal e segue para a cidade de Salvador, acompanhado de sua família: a esposa Hilda Muricy Melhor e seu único filho Carlos Anísio Melhor (ambos já são falecidos). Anísio despede-se de Nazaré com um texto que escreveu e leu para a cidade numa rádio local (por um sistema de alto-falantes). A dor da separação é expressa em cada linha de seu texto, como comprova o fragmento a seguir:

Eu te vim dizer adeus. Eu vim sentir no teu seio, oh mãe que estremeço, pela última vez...(quem sabe!) no calor do teu peito. Eu vim encostar a cabeça no teu colo, vim envolver no teu último carinho minha primeira saudade.

Partir! Somente os que amarguram as asperezas do afastamento sabem o que é partir, com saudade, isso que o poeta chamou: "levar a vida a fora o esquife da vida".

Não olhar mais o céu, a sua paisagem, que é a roupa da terra a fisionomia do seu povo, a imagem do seu berço, a graça, o sorriso, a louçania do crepúsculo que se vê com os sentimentos d'alma. Para os que vão saudosos, o mar soluça um choro de espumas... o caminho entristece à caída das tardes e às elevações do sol [...] (Melhor 1948)

Nos últimos anos de sua vida, residiu na cidade de Salvador no bairro do Tororó. Nesse período em que viveu na capital baiana, lia e escrevia textos para a Rádio Cultura da Bahia. A vida na capital foi acompanhada de dificuldades financeiras e de problemas de saúde vividos pelo poeta, que, acometido por um sério problema circulatório, tinha dificuldades de locomover-se. Faleceu aos 22 dias do mês de março de 1955, no hospital Português, em Salvador, onde encontrava-se gravemente enfermo. Seu corpo depois de embalsamado seguiu para Nazaré, seu berço estremecido conforme nota do jornal A Tarde, em 23 de março de 1955. Por volta de 1:30h da madrugada do dia 23 chegava a sua terra natal o corpo do ilustre escritor, acompanhado de pessoas de sua família, dentre elas a viúva Senhora Hilda Muricy Melhor e o único filho do casal, Carlos Anísio Melhor. O féretro foi conduzido por um grande número de pessoas para o salão nobre da Prefeitura Municipal, onde ocorreu o velório. Àquela época, o irmão do poeta, o Cel. Antônio dos Santos Melhor, era o prefeito de Nazaré. Ele cuidou do traslado do corpo do poeta para sua terra-berço. Muitas foram as homenagens àquele que tantos serviços prestou a sua terra: na imprensa, na educação, nas letras, na música, no teatro, no folclore, na filantropia, entre outros feitos. Sua morte causou profunda consternação a sua cidade.

\section{Entre o jornalismo e a literatura}

Anísio Melhor, desde a adolescência, demonstrava interesse pelos jornais. É o que ele mesmo afirma em uma de suas crônicas: "Quando a meninada do meu bairro trepava os cajueiros, jogava o pião e mergulhava o poço do Araçá, eu já retalhava os jornaes, collecionando versos e 
phantasias, formando volumes de miscelanias, como se chamavam esses livros de antologia popular" (Melhor 1934: f. 2).

Da reunião de alguns de seus folhetins, o escritor organizou e publicou o livro Idéias e Emoções - Folhetins D'o Conservador (s.d), uma coletânea composta por vinte e seis crônicas de sua autoria, publicadas em 0 Conservador. O folhetim, gênero textual tão utilizado por Anísio Melhor, é o texto-avô da crônica dos tempos atuais e surgiu no Brasil no século XIX por influência da imprensa francesa, apresentando-se com características semelhantes às do feuilleton. O termo folhetim era utilizado para designar romances publicados em capítulos nos rodapés de jornais. Também designava o espaço ocupado na primeira página do jornal. Desse modo, a crônica, o capítulo do romance ou a coluna propriamente dita, publicadas no jornal, poderiam ser chamados folhetim: um espaço privilegiado de regularidade semanal, que tornava o folhetinista conhecido. Essas características podem ser reconhecidas no folhetim anisiano, produzido nas primeiras décadas do século XX, em Nazaré.

Em Idéias e Emoções - folhetins D’O Conservador, o autor caminha por entre aspectos políticos, sociais, culturais e pessoais e enquadra-se no perfil do folhetinista:

Obrigatoriamente versátil, o folhetinista, colibri ou borboleta, deve ser capaz de passar em revista os principais acontecimentos da semana, sejam tristes ou alegres, sérios ou jocosos, econômicos ou políticos, sociais ou culturais. Tudo isso com as variações de estilo que cada assunto requer. (Faria 1992: 306)

O papel do folhetim O Conservador é registrar também os acontecimentos diários, por isso a sua importância histórica para o Recôncavo Baiano. Desse modo, o folhetim anisiano pertencia ao jornalismo por ser em sua essência informativo e muitas vezes crítico. Nele o literário insinua-se na informação, cedendo, muitas vezes, espaço para o devaneio, para as descrições sobre a natureza, apresentando muitos momentos em que o literário desbanca o que é puramente referencial. É o que acontece quando o autor apresenta as praias de Itaparica e conversa com uma interlocutora imaginária:

Lúcia - Esta é a cidade das belas paisagens. Um grande poeta das cores, artista e homem, retina e sensibilidade, arrancaria dessas praias para o enquadrado das telas, assombrosos trechos da natureza, harmonias admiráveis de cores e deslumbramentos.

Imagina, Lúcia, que o meu olhar se estende por águas azues e praias alvadias. Sinto-me debaixo de um cahir de tarde fresca e suave, vendo o sol a descer vermelho, brilhante. (Melhor s/d.: 3)

A interlocutora Lúcia aparece em muitas crônicas de Anísio Melhor, ela é a grande personagem de seus folhetins, aparece também em suas novelas e em muitos de seus contos:

Lúcia é um amor que venho guardando de criança [...] vive em todos os meus versos e nas páginas de todos os meus contos. Apareceu nas minhas novellas e eu tinha alegrias serenas, zelos de 
pae amoroso para ella, que se tornava creança, mal eu sentia hora por hora o caminho dos annos. E chamei-a "Maria Cabocla", "Maria das Graças", vi-a correr pelos campos, vi-a, num ímpeto de amor atirar-se no mar [...]

Outros, disse eu à graciosa leitora, chamam a dona destas cartas - Musa, Inspiração, Phantasia; chamo-a Lúcia, comprehende? (MELHOR: s.d., p. 22-24)

Não raro, Anísio Melhor dirige-se em suas crônicas ao leitor, como se pode perceber no texto "Sua Majestade o Homem". O uso do verbo no modo imperativo é uma constante em todo o texto e o cronista segue figurando seu leitor, como alguém que, paternalmente, deve lhe ensinar alguma lição. Não só a figura do leitor é destacada no texto, percebem-se os contornos do escritor, cujo perfil desvela impressões, experiências pessoais com que tenta conquistar a confiança, a cumplicidade dos leitores com suas digressões em torno dos que vencem pelo esforço e creem nos próprios ideais:

Caminha. Levanta a tua idéia, pesa-a na balança da tua consciência e faze della uma clava, para vencer embaraços e triumphar no espírito do povo. Aquelle que faz triumphar uma idéia collocou uma estrella no infinito. Anda; sê homem. A onda anonyma achata, porque é pesada [...] Sozinho, tu farás bem melhor que um cento. Lança a tua palavra ao vento e ella não terá a esterilidade da semente da parábola christã [...] (Melhor s/d.: 115)

Dentre os gêneros literários publicados em o Conservador, as crônicas são os que mais evidenciam o modus scribendi de Anísio Melhor, bem como apontam pistas de seu percurso intelectual e de sua evolução como escritor. E este gênero, antes de ser crônica propriamente dita, foi "folhetim", isto é, figurava nos rodapés dos jornais como artigo sobre os assuntos do dia, como diz Antônio Cândido em seu texto "A vida ao rés-do-chão":

Ora, a crônica está sempre ajudando a estabelecer ou restabelecer a dimensão das coisas e das pessoas. Em lugar de oferecer um cenário excelso, numa revoada de adjetivos e períodos candentes, pega o miúdo e mostra nele uma grandeza, uma beleza ou uma singularidade insuspeitadas. Ela é a amiga da verdade e da poesia nas suas formas mais diretas e também nas suas formas mais fantásticas, - sobretudo porque quase sempre utiliza o humor. (Cândido 1992: 14)

Antonio Cândido (1992: 165-166) afirma que encontrou as origens da crônica no Brasil no Correio Mercantil do Rio de Janeiro, particularmente entre as décadas de 1854 e 1855, num espaço de folhetim intitulado Ao correr da pena, sob a responsabilidade de José de Alencar, considerado importante escritor da literatura brasileira. $\mathrm{O}$ autor, semanalmente, discorria sobre temas da atualidade através de alguma crônica. Consoante Antonio Cândido, gradativamente, esse texto foi ganhando um aspecto despretencioso, pessoal e teve o seu tamanho reduzido, tornou-se um "gênero menor", o que o permitiu ser lido por um número cada vez maior de pessoas, pois o cronista utiliza-se de uma linguagem natural, que se aproxima do dia-a-dia; 
trata-se de um texto curto que foi enveredando cada vez mais na poesia e, numa versão mais moderna, ganhou um tom humorístico.

O cronista Anísio Melhor escreve do simples "rés-do-chão" (Cândido 1992: 165). A escrita anisiana não é a escrita de alguém que só observa os fatos. Ela vive dos fatos diários. De cunho revelador e insinuante, faz parte do dia-a-dia dos leitores dos jornais que colaborava. É, principalmente, no jornal, suporte transitório, que encontra abrigo. Quando a crônica passa do jornal ao livro, adquire maior durabilidade, podendo atravessar décadas, séculos. O escritor ao selecionar algumas crônicas dispersas no periódico O Conservador e publicá-las no livro intitulado Idéias e Emoções, certamente, desejou perpetuá-las.

Nada escapa aos olhos do cronista, ele precisa conhecer o presente, o passado e o futuro, como sinaliza a etimologia da palavra crônica. O cronista do passado organizava cronologicamente os acontecimentos, apresentando-os por meio da arte de escrever, para fixar os fatos que um dia fizeram parte do presente. Assim, a crônica do passado tinha o papel de historiar um período vigente ou que se revelava em documentos recentes. No tempo em que os jornais não existiam, os reis se valiam da crônica para guardar a memória dos acontecimentos importantes. A partir desses textos tinham-se imagens de sociedades passadas, via literatura.

Já o cronista moderno, que se utiliza do jornal, tem um papel mais leve, aproxima-se do leitor como numa conversa "ao pé-do-ouvido". Às vezes o cronista tem a notícia como ponto de partida para escrever o seu texto, mas, sem receios, vira as costas para ela, pois sua intenção não é necessariamente informar. A linguagem empregada nas crônicas anisianas aproxima o autor e leitor, pois o escritor investe a oralidade na escrita, tratando de tudo, oferecendo sua visão sobre acontecimentos que antes foram difundidos sem nenhuma emoção. Desse modo, a crônica é um gênero híbrido, situa-se na fronteira entre o jornalismo e a literatura; une a objetividade do jornalismo à subjetividade da literatura, como se pode comprovar na crônica "Carta Anônima", localizada no livro Idéias e Emoções (s.d.):

Lá fora um jovem intellectual matou-se. Um momento de desespero, uma carta anonyma apagou-lhe a vaidade de viver. $\mathrm{O}$ anonymato não deprime, levanta; Não ataca, defende; não mancha, purifica.

Valer-se do anonymato é cuspir injúrias ao vento; é morder sem dentes; é como envenenar a água; só degrada a quem o faz. O anonymato é a escuma da covardia. Matar-se por ser atacado pelo anônimo é julgar-se muito fraco, muito desiludido [...] (Melhor s/d: 36)

As crônicas, muitas vezes, revelam a auto-imagem do cronista. Em "A Tribuna e o Palládio" (1934), texto que homenageia esses dois periódicos interioranos, Anísio Melhor revela o que o jornal representa em sua vida:

O jornal não vale tanto pela decoração das gravuras e o tamanho do formato, como pelo mérito das idéias, o amor que se tem vinculado à terra do nascimento, porque todo o jornal tem vida, 
tem brios, enche-se de forças escondidas do patriotismo, de resistências heróicas para defender as causas que esposa. (Melhor 1934: 2)

Ainda nesse texto ele diz que tudo isso se encontra, não na simples folha do jornal, mas na figura máxima de seu dirigente. E discorre sobre o trabalho solitário do jornalista, aliando ao texto suas vivências enquanto leitor de jornais dos mais variados e, especialmente, enquanto jornalista de uma pequena cidade do interior baiano. O trabalho árduo do jornalista é o que ele quase denuncia ao confidenciar em uma de suas crônicas, "A Tribuna e o Paládio", repetidamente citada nos parágrafos seguintes: "Descobri-o no cérebro que age, muitas vezes numa salinha humilde, enobrecida, apenas, de livros; na mão que fez correr a penna sobre as tiras de papel, às vezes, retalhos da própria folha inutilizada pelo desacerto da máquina ou imprecisão da guilhotina" (ibidem).

Ele confessa que o desejo de tornar-se um jornalista nasceu a partir das experiências vividas e especialmente de seu fascínio pela leitura, pelas influências estéticas do poeta Castro Alves, dos contos de Coelho Neto e das crônicas de Pedro Ramos que eram publicadas nos jornais que ele colecionava. Além dessas revelações, o autor estabelece um paralelo entre os periódicos da capital e do interior baiano, e afirma que o jornal do interior apresenta-se distinto dos jornais da capital, visto que aquele nasce por uma necessidade e não por um simples capricho da ambição do jornalista. O momento em que ele viu de perto um jornalista, aos dezesseis anos de idade, está assim por ele relatado:

Trazia elle dentro da carteira de viajante os primeiros números de "O Paládio". E eu invejei aquele homem que sabia reunir em linhas, centenas de pedacinhos de chumbo para divulgarem coisas tão bonitas como os versos de Castro Alves, as phantasias de Coelho Neto e, pertinho de mim, as chronicas lapidares de Pedro Ramos! Via-me também viajante pela minha gazeta! (ibidem)

O cronista revela ainda o seu desejo em trabalhar na imprensa: "A minha vontade de trabalhar na imprensa teve grande influência naquele seu desassombro de periodista que não conhece obstáculos, fazendo de sessenta centímetros de papel, uma coisa tão útil nos lares sertanejos como o pão no almoço matutino de todos os domingos" (ibidem). Segundo o escritor, o jornal de interior valoriza cada leitor de sua cidadezinha, conhece seu público muito de perto, anota dia a dia os acontecimentos: ora é a crônica de cunho social, ora é o comentário sobre os falecimentos, ora é o nascimento de mais uma criança. Assim, constrói, a cada dia, a história dessa gente do interior, registra suas tradições, quase tudo construído por um só indivíduo.

Conforme o próprio escritor, três pessoas contribuíram para que ele trilhasse no caminho das letras: Affonso Costa, Rosendo Filho e Antonio Mendes. Affonso Costa foi para ele mais que um irmão, foi o responsável por levar o seu nome para fora dos limites de Nazaré, tornando-o conhecido nas sessões do Atheneu Moniz Barreto e na Academia de Letras da Bahia, sempre 
Cadernos de Literatura Comparada

Entre a Literatura e o Jornalismo: Itinerários do Escritor Baiano Anísio Melhor (1885-1955)

exaltando suas qualidades de literato e jornalista. Os outros dois amigos jornalistas influíram no seu espírito de forma diferente, sempre enviando notícias das matas e do litoral baiano.

Os periódicos A Tribuna (de Nazaré) e O Palládio (de Santo Antonio de Jesus) serviram de inspiração para o escritor, que os mantinha em sua mesa durante o processo de criação de seus textos. Ele confessa que antes de ler os jornais da capital ou os de fora da Bahia, lia todos os jornais do interior baiano, e desse contato diário com vários jornais ele se mantinha sempre bem informado e aperfeiçoava a cada dia suas habilidades de jornalista-autodidata. E cita outros jornais que faziam parte do seu cotidiano de leitor, ainda na crônica "A Tribuna e o Paládio":

Conheço "A Ordem", desde os tempos do velho José Ramiro, "A Pena" desde o tempo de João Gumes, a "Folha do Norte" do tempo em que Arnold Silva publicou o primeiro número; até os jornaes meninos de poucos annos, como o "Sudoeste", "A Cachoeira", "O Combate" e vejo na mocidade de Deraldo, de Laudionor e outros, aquella mocidade enthusiasta que já se vae tornando em sombras ao pé de minha figura. (Melhor 1934: 2)

Em sua crônica "Imprensa em Nazareth", publicada em julho de 1929 em O Conservador, o cronista apresenta um inventário com nomes de jornais e revistas que circularam em Nazaré com seus respectivos representantes. Trata-se de uma lista de 45 nomes, entre jornais e revistas, dos quais ele dizia possuir 31 deles, de alguns guardava coleção completa de mais de um ano. Dentre os jornais elencados que fizeram parte da vida da imprensa de Nazaré, pode-se citar, entre outros: O Regenerador (1901-1929), O Artista Nazareno (1873-1874); A Tribuna Liberal (1885-1887); O Trabalho, do redator Astério Embiruçu; A Semana, semanário político do diretor e proprietário Nestor Silva; A Cidade de Nazaré, do diretor e proprietário Pedro Ramos; $O$ Correio de Notícias, de propriedade e direção do professor Ferreira da Cunha; A Notícia, noticioso e político, de propriedade e redação de Ceciliano Souza. Além da participação em O Conservador, Anísio Melhor foi proprietário e/ou redator-gerente de outros órgãos de imprensa em Nazaré: A Ribalta, órgão da Escola Dramática A. Azevedo, cujos redatores eram Rosendo Filho e Anísio Melhor; A Cigarra, revista literária; O Asylo, órgão do Asylo de Meninos Desvalidos; e O Olho da Rua, jornal humorístico.

Conforme o depoimento do autor em sua crônica "Mistral relembrado", o exercício da leitura foi condição sine qua non para a sua formação intelectual: "se me fosse perguntado como eu comecei a amar os livros, como consegui dar forma aos pensamentos no trato obscuro das letras, eu responderia que levado pela imaginação de Alencar e Victor Hugo e Lamartine" (Melhor 1929: 2).

Muitas foram as vozes, outros livros que inspiraram Anísio Melhor. Alguns autores são citados em suas crônicas. Dentre os nomes mais citados por ele nos textos consultados, pôde-se enumerar os seguintes: Goethe, Cervantes, Botticelli, Miguel Ângelo, Victor Hugo, Benvenuto Cellini, Zola, Eça de Queirós, Afrânio Peixoto, Anísio Teixeira, Amadeu Amaral, Xavier Marques, Pedro Calmon, Pedro Barros, Fénelon, Montaigne. 
Além de revelar os papéis de literato e jornalista, o escritor Anísio Melhor registra em suas crônicas etapas do processo de produção dos seus textos e apresenta-se na condição de leitor das questões do seu tempo. Nos textos em estudo, flagramos a intervenção do homem intelectual, vocacionado a escrever, pensando o seu momento histórico, citando e comentando o pensamento de outros pensadores.

\section{Novelas de folhetins: retratos do Recôncavo Baiano na novelística de Anísio Melhor}

Muitos escritores brasileiros do século XIX e XX exercitaram a pena em jornais antes de se tornarem romancistas, isso porque não existiam, principalmente na região nordeste, políticas editoriais. Assim, os escritores encontraram nas revistas e nos periódicos uma forma de divulgar seus textos. Anísio Melhor utilizou-se desses meios massivos de comunicação para divulgar os gêneros literários que produziu, inclusive suas novelas, que apareciam capítulo a capítulo como folhetins do jornal 0 Conservador. Esta divulgação dos romances nos jornais ocorria também na Europa, mais especificamente na França nos fins do século XVIII. Hohlfeldt (2003: 20), sobre o gênero, assinala que toda ficção produzida na França na segunda metade do século XIX teve como meio de difusão o folhetim. Diz, também, que a democratização educacional, promovida pelo acesso à leitura, e o expressivo desenvolvimento tecnológico e a consequente queda dos custos tipográficos refletiam sobre a produção do livro e do jornal.

Segundo Hohlfeldt (2003), os romances-folhetim iniciam-se no Brasil com o Romantismo e seguem até o Naturalismo:

os escritores surgidos na maré do Romantismo brasileiro utilizariam o mesmo princípio para a divulgação de suas obras, e a circulação dos romances, no Brasil, através dos jornais, permaneceria até meados do século XIX, fazendo com que não apenas os textos românticos quanto os autores das tendências que se seguiriam, especialmente o Realismo e Naturalismo, adotassem o mesmo tipo de veiculação. Também os textos de peças teatrais consagradas chegaram a ser veiculados no espaço do folhetim. (Hohlfeldt 2003: 20)

Dessa forma, a maioria dos romancistas inicia sua carreira como contista pela facilidade na publicação desse gênero nos jornais. Anísio Melhor publicou um grande número de contos para o jornal 0 Conservador. A escrita de contos era exercício obrigatório para o romancista nordestino na época, bem como de romances confeccionados aos pedaços, apresentados capítulo a capítulo nos periódicos. No caso de Anísio Melhor, as novelas eram apresentadas capítulo a capítulo no periódico que fundou e dirigiu por trinta anos (O Conservador), impresso na sua própria tipografia. Com o advento do Modernismo, o regionalismo nordestino ganhou atenção nas letras nacionais, tanto nas produções em prosa quanto nas produções em verso.

Não se deve esquecer que as primeiras manifestações literárias no Brasil foram em versos. Reis (2004: 28) assevera "não ser nenhum exagero afirmar que até o início do século XX o verso, em relação à prosa, gozou de mais prestígio entre nossos escritores". Ainda segundo Reis (2004), isto por que o poema poderia ser propagado oralmente, já que a prática oral era costume 
Cadernos de Literatura Comparada

Entre a Literatura e o Jornalismo: Itinerários do Escritor Baiano Anísio Melhor (1885-1955)

na época e muito agradava ao público, e era mais facilmente publicado nos rodapés dos jornais.

Nas pequenas cidades não havia elementos de difusão literária. A solução foi a criação de jornais em que o literário pudesse ter lugar na vida cotidiana. Assim, vários jornais foram criados com o fim de abrigar escritores, popularizando a literatura por meio do jornalismo e contribuindo para a formação de leitores. Para tanto, os escritores desenvolveram uma técnica apropriada para a escrita desses textos folhetinescos, com o propósito de envolver os leitores, escrevendo textos de fundo impressivo, um jogo dramático, flagrante. Esses periódicos que se espalharam pelo interior baiano constituem importantes documentos para os estudos históricos e literários.

Anísio Melhor acompanhou o desenvolvimento literário e cultural das grandes cidades brasileiras, sem mesmo sair de Nazaré. Conforme seus escritos, mantinha-se informado através dos diversos jornais que lia e colecionava. De certa forma pode-se afirmar que ele seguiu a tendência francesa do romance-folhetim, criando um jornal, publicando capítulo a capítulo as suas novelas, além de contos, crônicas, poemas e trovas.

A ficção anisiana é marcada pela presença de elementos locais. Suas obras focalizam elementos regionais tais como o vaqueiro, o violeiro, os pescadores, a gente do interior, das praias e do campo e as suas tradições orais. Descrevem minuciosamente as paisagens do Recôncavo Baiano, apresentadas com elevado teor poético, em especial as suas novelas Maria Lúcia, Maria do Céu, Maria Cabocla e Almas Enfermas. Derramam-se em suas produções, sobretudo nas suas narrativas, recortes da história do Recôncavo, aspectos geográficos e muito do folclore baiano, representados de modo singular pela musicalidade das modas de viola, dos mitos e das lendas, dos lundus e dos versos que o autor fez questão de acoplar às suas criações em prosa, tudo isso transmitido através da personagem feminina, apresentando, assim, a mulher como pedra basilar na disseminação das tradições orais desta parte da Bahia.

Apesar de ter sido um nome pouco lembrado nas letras regionais, revestiu suas criações com a paixão que dedicou à cultura de sua região, coloriu-as com uma interpretação fiel, natural, sempre espontânea; produziu obras que exprimem movimento, como se fossem construídas em plena inquietação das lutas pela vida, como se as coisas mesmas é que falassem, sentissem, vivessem através do verbo esmerado do artista. Em seu artigo Literatura Baiana, publicado no jornal A Tarde em 17 de maio de 1984, o crítico Afrânio Coutinho diz que a literatura produzida na Bahia, no século XX, "é inteiramente desconhecida fora do estado. No entanto, é da maior relevância não só pelo número de figuras que nos diversos movimentos tomaram parte, muitas das quais cresceram em importância e projeção dentro e fora do estado, como também pela originalidade da criação a que deram lugar" (Coutinho 1984).

Segundo Coutinho (1984), no século XX, a literatura baiana foi caracterizada pelo surgimento sucessivo de movimentos gerados por grupos de intelectuais, homens de letras e artistas que criaram revistas que os representavam, além de cederem espaço para outras áreas do conhecimento humano. Dentre as revistas que circularam na sociedade baiana vale ressaltar neste estudo a revista A Luva (1925-1932), que surgiu num momento de crescentes debates sobre o modernismo e dos caminhos de consolidação deste movimento em algumas outras localidades do país. 
Nas páginas de A Luva há a junção dos elementos tradição e renovação, antigo e moderno, elementos que caracterizavam o tradicionismo dinâmico, e consistia em incorporar elementos inovadores na literatura sem, contudo, promover o aniquilamento das tradições; por isso defendia o retorno à tradição como fonte de renovação dos elementos que se apresentavam no presente (Alves 1986: 124-127). Essa perspectiva era defendida pelo crítico literário Carlos Chiacchio, considerado o mentor do Modernismo baiano e que exercia nítida influência entre os jovens escritores que enveredavam pelo caminho literário. Muitos foram colaboradores da revista, inclusive Anísio Melhor. Pode-se inferir que a obra literária anisiana é influenciada pelo tradicionismo dinâmico, visto que o autor pregava a busca pelas fontes nacionais, para uma releitura da arte, com incorporações de novos elementos, sem romper com os tradicionais. Conforme Anísio Melhor, na sua crônica "Gente sonhadora" (1931: 2), "até na arte a ânsia nossa é fazê-la inteiramente nossa. Quebrar velhos moldes de poesia que tem [sic] sido preciosos vasos de lavor estranho onde collocamos as flores do nosso sentimento, cheias do viço e da graça do ambiente brasileiro".

Afrânio Coutinho (1984), ao traçar breve histórico sobre a literatura modernista no Brasil e na Bahia, citou o trabalho importante de diversos escritores, entre eles Anísio Melhor:

Todos esses movimentos, expressos em revistas de vanguarda, mostram a riqueza com que o espírito baiano no século presente, demonstra o vigor das novas gerações, continuando a variedade e força que sempre caracterizaram a vida intelectual e artística do estado. É interessante assinalar que, no século, a sua atuação teve singularidade e características próprias, como é típica expressão também a grande produção da ficção regionalista de Lindolfo Rocha a Jorge Amado, Adonias Filho, Anísio Melhor, Xavier Marques, Afrânio Peixoto, Herberto Sales, os grandes do romance baiano. (Coutinho 1984)

A novelística anisiana compõe-se das obras Maria Lúcia (1916), Almas Enfermas (1921), Maria do Céu (1938) - novelas praieiras - e Maria Cabocla (1936) - novela histórica e regional. Elas bem exprimem o caráter da fiç̧ão anisiana, multifacetada, rica em aspectos, temas, formas e cores. O imaginário, o léxico, a feição popular das modas de viola, das lendas, das trovas e das estórias, o amor à sua terra e à sua gente - todo esse aparato compõe a grandeza de sua obra que assume a forma de um rico painel da cultura do Recôncavo. O narrador, sempre onisciente, ora capta os detalhes mais profundos do espaço em foco, ora penetra nos mais profundos anseios e desejos de suas personagens, um toque psicológico à Machado de Assis.

Anísio Melhor publicou grande parte de sua obra de ficção nas páginas do periódico $O$ Conservador. Esses textos, pelo valor histórico-literário que representam, não podem continuar dispersos, quase adormecidos nas páginas arquivadas desse periódico, como se tivessem sido escritos apenas para satisfazer interesses e exigências transitórias. Foi com eles que Anísio Melhor registrou a memória cultural local, enveredou pelo caminho das letras, descortinou-se como escritor em sua terra. Os folhetins, que escreveu para O Conservador, são grandes referenciais na sua vida de homem de letras. Os folhetins de suas novelas, por exemplo, 
Cadernos de Literatura Comparada

Entre a Literatura e o Jornalismo: Itinerários do Escritor Baiano Anísio Melhor (1885-1955)

tornaram o seu nome conhecido no cenário literário baiano em sua época.

Maria Lúcia é a sua primeira novela. O tema é a praia, o pescador, o conflito das paixões vivido entre a gente simples do Recôncavo baiano. É a descrição desses muitos poemas de amor que nascem e morrem à beira-mar. As cenas se passam em lugares onde os olhos do artista encontram as telas mais nítidas pintadas com esmero pela natureza: "A luz do sol se espalhava por tudo vagarosa e macia surpreendendo aos poucos o despertar da verdura tocada de orvalho" (Melhor 1916: 201). A imagem da protagonista, Maria Lúcia, que busca no suicídio a saída para o adultério, é envolta numa moldura romântica que se constrói ao longo da descrição das cenas finais da novela.

A novela praieira Almas Enfermas (1921) narra a trajetória da personagem Alzira Medrado e de sua filha, Annunciada, tendo como plano de fundo as paisagens naturais de Itaparica. A cidade, no decorrer da narrativa, é envolta em poesia:

Tintas differentes começaram a apparecer no céo. Faixas douradas, traços vermelhos, manchas louras passaram, se apagaram, se adensaram, ergueram-se em montanhas de ouro, esconderam-se atrás do Baluarte, sahiram, de novo, para a confusão das tintas, até o espontar das estrellas. [...] Itaparica assistia o morrer do sol, e ella toda era esse momento um traço de poesia das marinhas hollandesas, cheia de jogos e sombras, estremecimentos de luz, claridades indecisas. (Melhor 1921: 1)

Maria Cabocla, novela que foi publicada em 1936, tem alguns capítulos publicados em 1932, no periódico O Conservador, com a seguinte introdução feita pelo autor: "Novella histórica reconstituindo a vida, a physionomia local e os costumes de Nazareth, há quase dois séculos e gravando a linguagem da época" (Melhor 1932: 3). A escrita é para Anísio Melhor sua forma de dialogar com o mundo e consigo mesmo. Sua vida e sua escrita caminham em uníssono e uma revela a outra. Suas produções são tentativas de preservar, por meio do registro escrito, a memória do Recôncavo Sul da Bahia, sempre enfatizando experiências históricas coletivas, tudo isso mesclado às suas lembranças pessoais, aos seus sofrimentos, a suas alegrias.

As imagens da sua terra natal, em suas narrativas, deixam de ser exteriores e passam a ser interiorizadas pelo autor como imagens mnemônicas. Parafraseando Bolle (2000: 317318), apoderar-se da imagem da cidade significava, para o poeta, flagrar sua própria imagem. O sentimento de saudade pode ser observado em suas obras. Não se tratam de textos sobre o passado, mas da própria voz do passado. Ainda nas palavras de Bolle (2000:317), pode-se dizer que nenhuma historiografia faz o leitor sentir, com tamanha concretude, as sensações de uma época passada, a não ser por meio da sensibilidade e da memória afetiva do artista.

Na novela Maria Cabocla, há relatos históricos sobre a formação da cidade de Nazaré. Sem perder de vista as lendas que compõem as narrativas orais femininas, Anísio faz da tradição oral do Recôncavo o fundamento da sua literatura, tudo isso mesclado ao amor ingênuo vivido pelos personagens Maria Cabocla e Flávio. O cenário, entre as águas do Jaguaripe e as selvas, sofre um processo de humanização, como se fosse um prolongamento do ego do narrador e dos 
personagens. Dá-se ainda em suas obras um fusionismo entre campo e cidade, entre espaço e personagem, uma troca de características entre a natureza e as pessoas, conforme o fragmento transcrito a seguir: "No vale, o capim verde, alto, desdobrando-se numa manta aveludada, descia até à beira d'água, abraçando com as hastes moles e canudadas, pedras negras, postadas aqui e ali, formando um canal, por onde passava rumurante, orgulhoso, o Jaguaripe" (Melhor 1936: 83).

Essa novela compõe-se de imagens de espaços que desapareceram com o desenvolvimento da cidade de Nazaré. Esse talvez seja um papel a ser cumprido pelas suas novelas, já que os habitantes da cidade natal do escritor não vivem mais em ambientes em que se possam ouvir aquelas narrativas orais, os lundus, nem as cantigas que "de vez em quando, ouvia-se no alpendre o troço de arrieiros, reinós e naturais da terra, picando a unha na corda das violas e cantando motivos alegres e vadios" (Melhor 1936: 63-64). Segundo Giraudo (1997: 24): "a narrativa constitui um espaço utópico: o espaço em que o narrador 'retorna' aos lugares que deixou, e o espaço em que constrói os lugares em que nunca esteve". Desse modo, a novelística anisiana é um veículo de cristalização da memória da gente do Recôncavo Sul Baiano, expressa também sua preocupação com o resgate de experiências especificamente femininas e de tudo que delegue forma à vida cotidiana da gente dessa parte da Bahia.

Os capítulos são apresentados com delicadeza e, numa explosão sensorial de cores, aromas e sons, o autor enfatiza a sua terra natal, Nazaré, que parece ser antes um desdobramento imagético da figura feminina do que mero espaço e/ou cenário, evidenciando uma metaforização de sua cidade em grau máximo: "E metaforizamos também aquilo que amamos, aquilo que desejamos deter-nos e contemplar, ver de todos os ângulos e a todas as luzes, espelhado em várias incidências, por todas as espécies de coisas semelhantes" (Wellek e Warren 1955: 233).

As serras, o rio, o verde, desde os acidentes do relevo à pintura heterogênea dos costumes, figuram com tamanha assiduidade que se dá um encontro destes símbolos com o homem afeito às cores e aos perfumes. Em alguns momentos da obra, o poeta "caminhava" por uma Nazaré em processo de expansão econômica:

Alargando-se na fartura das searas, progredindo na expansão do comércio e nos ofícios que acudiam as necessidades mais vivas, a terra amanhecente, umedecida pelo espraiado manso do Jaguaripe, resplandecia na graça verde das alfombras do vale, escutando a música branca do maracá selvagem dos ventos. (Melhor 1936: 46)

Em sua novela Maria do Céu, mais imagens de sua terra natal: "Nazareth envolvida no véu da noite tinha salpicando [sic] a sua figura de cidade comercial focos de iluminação profusa e faiscante" (Melhor 1938: 47).

Em se tratando do sofrimento amoroso, as personagens protagonistas são dotadas de doçura e de bondade, são imagens cândidas, como inspirados retratos ao natural, sendo este também o perfil de sua personagem Maria do Céu que dá nome à novela publicada em 1938, e o perfil de Anunciada protagonista de Almas Enfermas. Na descrição do personagem, nenhum 
exagero nos traços, nenhuma demasia nas tintas. Cuida ainda de adequar o vocabulário a cada personagem. No prefácio de Maria do Céu, o depoimento emocionado do autor: "A minha preocupação em 'Maria do Céu' não foi urdir o assunto e vestir as figuras; tentei mais: fui buscar para elas os sofrimentos da alma e a bondade do coração. E derramei pelo meio lágrimas que vinha trazendo dos vexames da vida" (Melhor 1938: 1).

Vale destacar, portanto, o valor estético e a importância documental do conjunto da obra de Anísio Melhor para a Literatura Baiana do século XX: são produções artísticas que surgiram para apresentar a candura, a poesia dos retratos humanos ou paisagísticos do Recôncavo Sul da Bahia. Uma obra composta por uma diversidade de gêneros textuais que necessitam ser submetidos a leituras, discussões e estudos aprofundados.

\section{Considerações finais}

Pode-se inferir da leitura dos arquivos sobre Anísio Melhor que ele é um dos muitos exemplos de escritores que, pelo valor estético de sua produção e pela sua versatilidade, poderia manter-se lembrado, ao menos, nos artigos e ensaios produzidos em sua terra natal. E suas obras poderiam ter sido reunidas, re-editadas. Ao contrário, encontram-se dispersas em arquivos baianos, se decompondo com o passar dos anos. Algumas estão desaparecidas e, possivelmente, permanecerão figurando apenas nas antigas listas (incompletas) das produções literárias do escritor. Uma hipótese que pode ser levantada sobre o autor encontrar-se atualmente esquecido é o fato de ele ter vivido numa pequena cidade do interior, um tanto distante do furor literário-cultural que a capital baiana vivia na primeira metade do século $\mathrm{XX}$. Acredita-se, também, que este esquecimento se deu pela dificuldade que encontrou na publicação de seus livros e, por consequência, da dificuldade em criar um público leitor e uma opinião crítica em torno de suas obras, tal como outros escritores de sua época.

Somando-se a essas hipóteses levantadas, está o fato de Anísio Melhor ter encontrado no jornal o espaço para expor seus contos, crônicas, poemas e capítulos de suas novelas. O descaso com que essa mídia era tratada pela alta literatura, ou pelo cânone, àquela época, pouco estimulava o crítico literário a escrever sobre os textos, pois acreditava-se que estes tinham apenas a finalidade de entreter o leitor. Os autores que publicavam nesse espaço eram considerados autores menores, pois a tiragem e a continuidade dos jornais davam um caráter efêmero às suas produções. Muitas crônicas e contos de Anísio Melhor, por exemplo, encontram-se dispersos e ainda não houve quem os reunisse em um livro.

Objetivou-se com este trabalho apresentar um pouco do labor que se tem empreendido com o intuito de resgatar os textos de Anísio Melhor dispersos em arquivos baianos e em especial no periódico O Conservador que circulou em Nazaré (BA) de 1912 a 1945. Acredita-se que ao resgatar e estudar esses textos contribui-se para que a história da gente do Recôncavo Baiano, neles presentes, seja preservada. Os textos de Anísio Melhor transportam o leitor ao passado de Nazaré, ao cenário cultural, social e econômico da época em que foram construídos e circularam em jornais baianos. Nisso reside a importância do trabalho filológico: resgatar textos que se encontram dispersos, silenciados nos arquivos. 


\section{NOTA}

* Ionã Carqueijo Scarante é doutora em Literatura e Cultura, pela Universidade Federal da Bahia (UFBA), Mestre em Cultura, Memória e Desenvolvimento Regional (UNEB), Especialista em Língua Portuguesa: Texto (UEFS), Especialista em Planejamento e Gestão de Sistemas de Educação a Distância (UNEB), Graduada em Letras (UNEB). Professora do Instituto Federal de Educação, Ciência e Tecnologia Baiano (IF BAIANO-Campus Valença), Membro do Grupo de Pesquisa em Linguagens, Culturas e Ambientes (GLICAM). Poeta. Desenvolve pesquisas na área da Crítica Literária e da Filologia, com ênfase na edição crítica da produção literária de autores do Recôncavo e Baixo Sul baianos. É organizadora das antologias Mãos que inspiram poesia: a arte de Maragogipinho traduzida em versos e ilustrações (2020); Poesias no Jardim (2019) e Mulheres Poetas (2021).

\section{Bibliografia}

Alves, Lizir Arcanjo (1986), Poesia e vida literária na Bahia de 1890 a 1915. São Paulo, 250 f. Dissertação (Mestrado em Letras) - Faculdade de Filosofia, Letras e Ciências Humanas, USP, São Paulo.

Araújo, Antônio Mendes (1945), "Os que se distinguem pelo próprio esforço", in O Paládio, Santo Antonio de Jesus. p. 1. (Recorte de Jornal).

Bolle, Willi (2000), Fisiognomia da Metrópole Moderna: Representação da História em Walter Benjamin. 2. ed., São Paulo, EDUSP.

Cândido, Antonio (org.) (1992), A crônica: o gênero, sua fixação e suas transformações no Brasil. Campinas, São Paulo, EDUNICAMP; Rio de Janeiro, Fundação Casa de Rui Barbosa.

Coutinho, Afrânio (1978), Notas de teoria literária. 2. ed., Rio de Janeiro, Civilização Brasileira.

-- (1984), "Literatura Baiana", A Tarde, Salvador, 17 maio. (Recorte de jornal localizado na Fundação Lamartine Augusto).

-- / SOUSA, J. Galante de (2001), Enciclopédia de literatura brasileira. 2. ed., rev., ampl., atual., il. São Paulo, Global; Fundação Nacional; Academia Brasileira de Letras, v. 1.

Crusoé, Oswaldo (1978), Monografia de Anísio Melhor. Nazaré - BA. Texto datilografado pertencente ao acervo da Fundação Lamartine Augusto.

Faria, João Roberto (1992), "Alencar: a semana em revista", in Cândido, Antonio (org.), A crônica: o gênero, sua fixação e suas transformações no Brasil. Campinas, EDUNICAMP; Rio de Janeiro, FCRB, p. 306.

Giraudo, José Eduardo Fernandes (1997), Poética da Memória: uma leitura de Toni Morrison. Porto Alegre, Editora da UFRGS.

Hohlfeldt, Antonio (2003), Deus escreve direito por linhas tortas: o romance-folhetim dos jornais de Porto Alegre entre 1850 e 190o. Porto Alegre, EDIPURCS. 
Lowenthal, David (1998), "Como conhecemos o passado". Trad. Lúcia Haddad. Revista projeto História: Trabalhos da Memória, Programa de Estudos Pós-graduados em História da PUC/ SP. São Paulo, EDUC, n. 17, nov., p. 83.

Matta, João Eurico (1990), "Tristeza e Alegria no Poeta e cronista Anísio Melhor". Revista da Academia de Letras da Bahia, Salvador, jan., n.36, p. 191-192.

Melhor, Anísio (1955), "Adeus a Nazaré. Carta", in Jornal A Tarde, Suplemento Literatura e Arte, Salvador, 19 de maio.

-- (1929), “A Imprensa em Nazareth", o Conservador, Nazaré, 14 jul., n. 7, p. 2.

- (1921), "Almas Enfermas", Nazaré, Esc. Tip. Meninos do Asilo.

- (1934), "A Tribuna e o Paládio", o Conservador, Nazaré, 19 nov., n.17, p. 2.

-- (1931), "Gente sonhadora", o Conservador, Nazaré, 8 nov., n. 15, f. 2.

-- [s.d.], Idéias e Emoções: folhetins D’O Conservador, Nazaré.

- (2002), Maria Cabocla. 2 ed., Salvador, Gráfica Bahia.

- (1938), Maria do Céu. Nazaré, Esc Tip. Meninos do Asilo.

-- (1916), Maria Lúcia. Nazaré, Esc. Tip. Meninos do Asilo.

- -(1911), Meus versos: a coleção dos primeiros. Nazaré, Tipografia Aurora.

- - (1929), "Mistral relembrado". o Conservador, Nazaré, 26 nov., n. 17, p. 2.

Reis, Maria da Conceição Souza (2004), O Sampauleiro: romance de João Gumes. 520f. Tese (Doutoramento em Letras), Programa de Pós-Graduação em Letras e Lingüística, Instituto de Letras, Universidade Federal da Bahia, Salvador.

Wellek, Renée e Warren, Austin (1955), Teoria da Literatura. Trad. José Palla e Carmo, Portugal, Publicações Europa-América, 4. ed. [s. d.].

Zilberman, Regina/ Moreira, Maria Eunice/ Bordini, Maria da Glória/ Remédios, Maria Luiza Ritzel (2004), "Fontes - porque primárias", in Zilberman, Regina/ Moreira, Maria Eunice/ Bordini, Maria da Glória/ Remédios, Maria Luiza Ritzel (org.), As pedras e o arco; fontes primárias, teoria e história da literatura. Belo Horizonte, EDUFMG. 